\title{
Role of microsatellites in genetic analysis of Bombyx mori
}

\section{silkworm: a review [version 1; peer review: 2 approved]}

\author{
Julian David Trochez-Solarte (iD1, Ximena Ruiz-Erazo1, Martha Almanza-Pinzon', \\ Giselle Zambrano-Gonzalez (iD)2
}

\footnotetext{
${ }^{1}$ Agropecuary Sciences Department, Production Integrated Systems Research Group (SISINPRO), Faculty of Agricultural Sciences, University of Cauca, Popayán, Cauca, 190017, Colombia

${ }^{2}$ Biology Department, Geology, Ecology and Conservation Research Group (GECO), Faculty of Natural Sciences and Education, University of Cauca, Popayán, Cauca, 190002, Colombia
}

V1 First published: 13 Aug 2019, 8:1424
https://doi.org/10.12688/f1000research.20052.1

Latest published: 13 Aug 2019, 8:1424

https://doi.org/10.12688/f1000research.20052.1

\section{Abstract}

In the genome of Bombyx mori Linnaeus (1758), the microsatellites, or simple sequence repeats (SSR), feature among their particular characteristics a high adenine and thymine (A/T) content, low number of repeats, low frequency, and a grouping in "families" with similar flanking regions. Such characteristics may be the result of a complex interaction between factors that limit the size and dispersion of SSR loci-such as their high association with transposons-and mean that microsatellites within this taxon suitable as molecular markers are relatively rare. The determination of genetic profiles in populations and cell lines has not been affected owing to the high level of polymorphism, nor has the analysis of diversity, structure and genetic relationships. However, the scarcity of suitable microsatellites has restricted their application in genetic mapping, limiting them to preliminary identification of gene location of genes or quantitative trait loci (QTLs) related to thermotolerance, resistance to viruses, pigmentation patterns, body development and the weight of the cocoon, the cortex, the pupa and the filament. The review confirms that, as markers, microsatellites are versatile and perform well. They could thus be useful both to advance research in emerging countries with few resources seeking to promote sericulture in their territories, and to advance in the genetic and molecular knowledge of characteristics of productive and biological interest, given the latest technological developments in terms of the sequencing, identification, isolation and genotyping of SSR loci.

\section{Keywords}

Bombyx mori, silkworm, molecular marker, sericulture, Simple

Sequence Repeats, SSR.

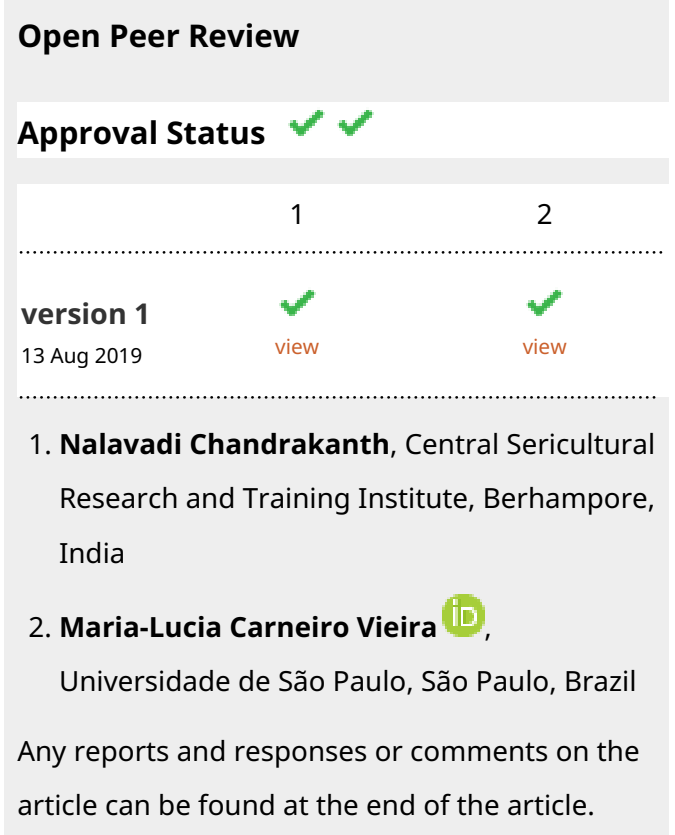


Corresponding author: Julian David Trochez-Solarte (juliantrochez@unicauca.edu.co)

Author roles: Trochez-Solarte JD: Writing - Original Draft Preparation; Ruiz-Erazo X: Writing - Review \& Editing; Almanza-Pinzon M: Writing - Review \& Editing; Zambrano-Gonzalez G: Writing - Review \& Editing

Competing interests: No competing interests were disclosed.

Grant information: The author(s) declared that no grants were involved in supporting this work.

Copyright: (c) 2019 Trochez-Solarte JD et al. This is an open access article distributed under the terms of the Creative Commons Attribution License, which permits unrestricted use, distribution, and reproduction in any medium, provided the original work is properly cited.

How to cite this article: Trochez-Solarte JD, Ruiz-Erazo X, Almanza-Pinzon M and Zambrano-Gonzalez G. Role of microsatellites in genetic analysis of Bombyx mori silkworm: a review [version 1; peer review: 2 approved] F1000Research 2019, 8:1424 https://doi.org/10.12688/f1000research.20052.1

First published: 13 Aug 2019, 8:1424 https://doi.org/10.12688/f1000research.20052.1 


\section{Introduction}

Domesticated around 5,000 years ago, the silkworm, Bombyx mori L. is the basis of sericulture, an agroindustrial activity that involves the breeding of silkworms, cultivation of Morus spp. mulberry plants as the sole source of food, and industrial processing of cocoons to produce natural silk yarn ${ }^{1}$. B mori is an ideal organism as an experimental animal for genetic and biological research. Silkworms are easily reared and produce a genetically uniform population. This, added to their economic importance, has made $B$. mori one of the most widely studied insects $^{2,3}$. As a result, genetic materials of agronomic and scientific interest have been identified, characterized and conserved ${ }^{4}$ using a variety of molecular markers, prominent among them microsatellites, or simple sequence repeats (SSRs).

Microsatellites are regions of DNA in which a sequence or motif between 1 and 6 bp is repeated in tandem 5 to 100 times, the number of repeats of the same locus being highly variable both inter- and intra-populationally. They are also ubiquitous, distributed uniformly in eukaryotic genomes ${ }^{5}$. SSR loci are usually flanked by regions of unique sequence, which allows PCR amplification with specifically designed primers and determination of the specific genetic profile or genotype of an individual for several loci through the pattern of bands displayed on capillary sequencing equipment ${ }^{5}$. These markers are codominant and highly polymorphic. They have greater reproducibility and band comparability, are less sensitive to contamination by foreign DNA (due to their specificity) and can be amplified using fragmented or partially degraded DNA, because of the reduced size of the loci ${ }^{6}$.

These molecular markers have been a useful tool in sericulture, especially in the management, characterization and conservation of materials in germplasm banks ${ }^{7,8}$ and in the development of genetically improved materials ${ }^{9}$. They have been particularly difficult to apply, however, to genetic mapping, mainly due to the low frequency of loci suitable as molecular markers in the $B$. mori genome. Their contribution in this area has therefore been restricted to preliminary mapping of some genes and QTLs related to characteristics of productive interest ${ }^{10}$ or to processes of $B$. mori body development and pigmentation ${ }^{11,12}$.

The review focuses on the description and analysis of the specific characteristics of microsatellites in the $B$. mori genome, the role these repetitive DNA regions have played as molecular markers in this organism, and how these would play an important role in future in the genetic analysis, conservation and use of silkworm germplasm.

\section{Characteristics of silkworm genome microsatellites}

Microsatellite characteristics-distances between loci, abundance, distribution, motif and the average number of repeats they comprise-may vary among taxa ${ }^{13}$. The B. mori microsatellites feature average distances of between 49 and $161 \mathrm{~kb}^{14,15}$, their genome coverage is only $0.31 \%^{16}$ and they have a cloning efficiency of between 0.77 and $3.5 \%{ }^{14,15}$. Together, such values indicate that microsatellites in the $B$. mori genome are rare. The pattern is not unusual however, having been observed in other insect species, including several in the Drosophila genus $^{17,18}$.

SSR loci with mononucleotide-like motifs represent $60 \%$ of the microsatellites of the B. mori genome, high compared to other insect species ${ }^{17}$, and are formed by a low number of repeats, nine on average among the different repeat motifs. Loci of more than 15 repeats are scarce, except for mononucleotide motifs ${ }^{16,17}$. Harr and Schlötterer ${ }^{19}$ report that Drosophila melanogaster Meigen (1830) also has short SSR loci on average $(<15$ repeats), because the greater the length, the greater the tendency of the D. melanogaster microsatellites to mutations that decrease the number of repeats instead of increasing it. This is speculated to be the result of interaction between factors related to DNA repair and replication mechanisms.

The B. mori genome has a comparatively high composition of regions rich in adenine and thymine $(\mathrm{A} / \mathrm{T})$. Moreover, the microsatellites that include a high proportion of these bases are the most abundant, constituting approximately $40 \%$ of the dinucleotide motifs and $28.3 \%$ of the total ${ }^{20}$. Such a predominance has not been seen in other organisms ${ }^{16,20}$.

Transposons appear to play a key role in the evolution of microsatellites in the B. mori genome ${ }^{21}$. Of the B. mori SSR loci, $35 \%$ are grouped into "families" with flanking regions similar in sequence. This is due to their association with transposons ${ }^{17}$, mobile genetic elements capable of replicating themselves and associated regions. Transposons account for 35-43.6\% of the B. mori genome ${ }^{22,23}$. For Meglécz et al. ${ }^{17}$, this high association suggests one of two scenarios: transposons might favor the development of microsatellites in their vicinity, or promote their formation at the moment of transposition. It is possible, however, that they have no part to play in the genesis. The SSR loci could develop independently, but have a structure that favors the insertion of mobile elements ${ }^{24}$.

The characteristics of the B. mori microsatellites-low frequency, low average number of repeats, and grouping in families-are common to the Lepidoptera order. They explain the difficulties in isolating single copy microsatellites ${ }^{17,18,25,26}$, but the advance in high-throughput sequencing techniques and graph-based cluster analysis ${ }^{27}$, as well as screening against transposons elements in the isolation procedure ${ }^{28}$ may in future facilitate identifying suitable microsatellites for genetic studies in species in this taxon.

Zhang ${ }^{21}$ suggested that the characteristics of Lepidoptera microsatellites imply that, in their respective genomes, most have experienced a recent development and multiplication, in the different lepidopteran species. This may mirror that reported in D. melanogaster ${ }^{19}$, characterized because its long SSR loci are of recent origin and have short prevalence periods.

Microsatellite evolution is extremely complex ${ }^{24}$. The characteristics in B. mori and the Lepidoptera, as well as in other organisms ${ }^{29}$, appear to result from interaction in the genome between the mutations or events that cause them and the factors that 
obstruct or limit their development, with a balance in favor of the latter in silkworm. The key to the low average number of repeats and low frequency of SSR loci in the B. mori genome may be the abundance of $\mathrm{A}$ and $\mathrm{T}$ bases, and of microsatellites composed of these bases. Regions rich in A/T have a higher frequency of double-strand breaks in the DNA, which can induce and facilitate both the loss of nucleotides during non-homologous recombination $^{30}$ and the insertion of transposons able to divide an SSR locus in two and interrupt its development ${ }^{24,31,32}$. This could explain why A/T-rich microsatellites in B. mori have a lower average number of repeats, as reported by Zhan et al. ${ }^{20}$.

Additionally, the presence in B. mori of an efficient DNA mismatch repair mechanism, the system in charge of correcting the incorrect incorporation of bases ${ }^{29}$, could counteract replication slippage, the major mutational mechanism in explaining the origin and evolution of repetitive DNA regions ${ }^{24}$.

\section{Applications of microsatellites}

\section{Construction of DNA profiles}

Microsatellites have proved a useful tool for generating band patterns that enable discrimination of silkworm lines. Kim et al. ${ }^{8,33,34}$ found that $25-28 \%$ of the amplified alleles are specific to the lines, due to which a small number of microsatellites, one to three, allow identifying approximately $20 \%$ of the analyzed materials without resorting to the genotyping of other loci. Hou et al. ${ }^{35}$ and Chandrakanth et al. ${ }^{36}$ likewise indicate that the analyzed genotypes are homozygous for a substantial part of the microsatellites used. Since each locus is multiallelic, those that amplify as a single band in each line are powerful tools for identification, as demonstrated by $\mathrm{Li}$ et $a .^{37}$ when discriminating between two closely related lines identical in their morphological characteristics: Dazao and P50.

DNA fingerprinting also represents a tool for the identification of insect cell lines. Between 3 and 8 microsatellites have therefore been used to generate profiles of cell lines susceptible to the nuclear polyhedrosis virus of B. mori (BmNPV), developed to study replication and expression mechanisms of the virus ${ }^{38-40}$. McIntosh et $a l .{ }^{41}$ obtained stable DNA profiles even after performing 200 subcultures by using coding regions (aldolase, prolactin receptor, interleukin-1 $\beta$ ) as molecular markers. Microsatellites are less stable, however, due to their high mutation rate-between $10^{-4}$ and $10^{-6}$ per locus per generation ${ }^{42}$. Thus, for future identification of cell lines, it is advisable to evaluate and select SSR loci that present relatively low mutation rates.

\section{Analysis of genetic diversity}

Sericulture depends on the strategic use of silkworm germplasm to develop hybrids with high yields of silk that resist or tolerate disease and adverse climatic conditions ${ }^{43}$, based on knowledge of the extent and distribution of the genetic diversity available in both the domesticated silkworm B. mori and its wild relative Bombyx mandarina Moore (1872). In this context, between 500 and 700 microsatellites were developed in B. mori, of which 5 to 27 markers have been used for analyzing genetic diversity (Table 1).
Miao et al. ${ }^{15}$ and Zhan et al. ${ }^{20}$ discovered that the genome of B. mori lines with contrasting characteristics is similar, in terms of the low percentage of polymorphic SSR loci, ranging between $17 \%$ and $24 \%$ compared, for example, with $85 \%$ for the European bee, Apis mellifera ${ }^{44}$, and $55 \%$ in laboratory rats ${ }^{45}$. Together, these data attribute the origin of $B$. mori to a single domestication event from a reduced population of $B$. mandarina ${ }^{15}$. Xia et $a .^{46}$, however, on conducting a complete genome analysis on domesticated lines and wild individuals report that $B$. mori harbors $83 \%$ of the genetic variability of wild populations, indicating that the origin was possibly not limited to a reduced population or a single domestication event ${ }^{43}$.

The low percentage of polymorphic SSR loci found among domesticated lines of $B$. mori should not be interpreted as evidence of the reduction of genetic diversity with respect to wild populations. The low figure could instead be the result of size homoplasy, a process of change by which convergent mutations cause microsatellites, belonging to different lineages, to have the same length in base pairs ${ }^{47}$.

Size homoplasy is favored when mechanisms are present that neutralize elongation of the microsatellites and limit the number of repeats, since possible alleles are reduced and mutations are more likely to converge in the same length. These conditions appear to be present in the B. mori genome, in which most microsatellites are of reduced size ${ }^{16,17,20}$. In 2016, De Barba et al. ${ }^{48}$ proposed a new method for genotyping microsatellites using high-throughput sequencing; this would allow direct access to the microsatellite sequences in $B$. mori and evaluate whether the low percentage of polymorphic loci is due to the presence of size homoplasy.

Although B. mori has not experienced a drastic reduction in genetic diversity compared to $B$. mandarina, the wide genetic distances between domesticated and wild populations ${ }^{49}$ indicate that these species have a marked genetic differentiation and distant relationships. This is likely due to the absence of genetic flow, a result of the inability of $B$. mori to fly and to survive without human intervention ${ }^{50}$. Thus, B. mandarina represents a potential unique source of genetic material for sericulture $^{43}$.

Cluster analyzes to determine the relationships between $B$. mori lines provide contradictory results. Reddy et $a l .{ }^{14}$, Qian et al. ${ }^{51}$, Thiyagu and Kamble ${ }^{52}$ and Chandrakanth et al. ${ }^{36}$ report that grouping the materials based on the microsatellites analyzed corresponded to type of voltinism, geographical origin, silk productivity, color or shape of the cocoon. However, the groups formed in studies that analyzed a larger sample of germplasm-69 lines on average, compared to 18 in the works cited above-exhibit mixtures of genotypes with variability in these characteristics $^{8,33-35,37}$.

Several different scenarios may explain why $B$. mori genotypes, with apparently diverse traits, are grouped together, the main one being the hybridization that has historically been used, in pure lines, to perform the introgression of genes that increase 
Table 1. Studies of genetic diversity conducted in B. mori using microsatellites.

\begin{tabular}{|c|c|c|c|c|}
\hline Reference & $\begin{array}{l}\mathrm{SSRs}^{\dagger} \text { and } \\
\text { alleles }\end{array}$ & $\mathbf{P I C}^{\ddagger}$ & $\begin{array}{l}\text { Genotypes } \\
\text { and groups }\end{array}$ & Results \\
\hline Reddy et al., $1999^{14}$ & 15 and 113 & - & 13 and 2 & $\begin{array}{c}\text { Identification of specific alleles of lines with diapause and } \\
\text { without diapause. }\end{array}$ \\
\hline Zhang et al., $2005^{49}$ & 27 and 146 & $0.57-0.88$ & 12 & $\begin{array}{l}\text { The diversity in highest in } B \text {. mandarina populations, followed } \\
\text { by Chinese, Japanese and European lines of } B \text {. mori. }\end{array}$ \\
\hline Li et al., $2005^{37}$ & 26 and 188 & $0.12-0.89$ & 31 and 7 & $\begin{array}{c}\begin{array}{c}\text { Groupings with mixtures of genotypes of different types of } \\
\text { voltinism. }\end{array}\end{array}$ \\
\hline Hou et al., $2007^{35}$ & 35 and 467 & $0.30-0.92$ & 96 & $\begin{array}{c}\text { Groups composed of mixtures of genotypes with different } \\
\text { types of voltinism and geographic origin. The greatest } \\
\text { diversity in lines of Chinese origin. }\end{array}$ \\
\hline Qian et al., $2007^{51}$ & 11 and 106 & - & 40 & $\begin{array}{c}\text { The groupings coincide with differences in geographical } \\
\text { origin and voltinism. }\end{array}$ \\
\hline Vijayan et al., $2010^{53}$ & 7 and 49 & $0.10-0.40$ & 13 and 2 & $\begin{array}{c}\text { Genotypes with contrasting characteristics could be crossed } \\
\text { to obtain hybrid vigor in their offspring. }\end{array}$ \\
\hline Kim et al., $2010^{33}$ & 9 and 68 & $0.06-0.86$ & 54 & $\begin{array}{c}\text { The groupings do not coincide with phenotypic } \\
\text { characteristics of the lines. On detecting } 17 \text { unique alleles, it } \\
\text { was possible to identify } 14 \text { lines. }\end{array}$ \\
\hline $\begin{array}{l}\text { Thiyagu and Kamble, } \\
\qquad 2011^{52}\end{array}$ & 10 and 139 & - & 10 and 4 & $\begin{array}{l}\text { The grouping coincided with differences in geographical } \\
\text { origin and silk productivity of the lines evaluated. }\end{array}$ \\
\hline Kim et al., $2012^{8}$ & 8 and 76 & $0.34-0.82$ & 85 & $\begin{array}{c}\text { On detecting } 22 \text { unique alleles, it was possible to identify } \\
19 \text { lines. The groups formed do not coincide with known } \\
\text { phenotypic characteristics. }\end{array}$ \\
\hline Chu and Peng, $2013^{54}$ & 22 & $0.0-100$ & 23 and 2 & The lines were divided into 2 groups. \\
\hline $\begin{array}{l}\text { Chandrakanth et al., } \\
\qquad 2014^{36}\end{array}$ & 15 and 54 & $0.16-0.75$ & 10 and 4 & $\begin{array}{l}\text { The groups coincide with the geographical origin, and the } \\
\text { subdivision coincides with the color or shape of the cocoon. }\end{array}$ \\
\hline Furdui et al., $2014^{7}$ & 5 and 31 & $0.35-0.67$ & 15 & $\begin{array}{l}20 \% \text { of the genetic variance is between genotypes. Lines } \\
\text { with wide genetic distances and contrasting characteristics } \\
\text { are useful for developing new hybrids. }\end{array}$ \\
\hline Kim et al., $2014^{34}$ & 8 and 73 & $0.37-0.77$ & 78 & $\begin{array}{c}\text { The groupings do not coincide with the phenotypic } \\
\text { characteristics of the lines. On detecting } 19 \text { unique alleles, it } \\
\text { was possible to identifying } 16 \text { lines. }\end{array}$ \\
\hline
\end{tabular}

† SSRs: microsatellite loci used (Simple Sequence Repeats)

‡ PIC: polymorphic information content (PIC) ranking of microsatellites within the study

silk yield or survival rate in various environmental conditions $^{55-58}$. This would alter their phenotypic characteristics but, due to backcrossing, they would maintain a similar-or even the same-genotype, depending on the microsatellites analyzed.

Various pure lines may also share an origin in the same ancestral population of $B$. mandarina, but would have been selected to express different phenotypes, maintaining a high similarity at the genotypic level ${ }^{7,37,59}$. This might also explain why pure lines with similar characteristics are not always grouped, given that they would have a distant relationship, but would have been selected to express similar traits ${ }^{35,37}$.

Traditional genetic improvement in B. mori implies the use of phenotypic characteristics or geographical origin to differentiate and select parents with contrasting characteristics with which to perform crosses. However, due to the scenarios already mentioned, these characteristics do not always make it possible to accurately determine genetic relations between materials ${ }^{60}$. Microsatellites thus represent an important tool for making accurate estimates of genetic diversity and relationships in order to develop genetically improved materials (hybrids), bearing in mind that, comparatively, performance is better than that of other markers such as RAPDs, RFPLs and ISSRs ${ }^{6}$.

Microsatellites not only represent a marker with a good performance in analysis of genetic diversity in B. mori. They constitute a versatile tool that can be adjusted to meet the research requirements and the resources available. For example, they can potentially be genotyped with high-throughput sequencing for greater accuracy ${ }^{48}$ and even be identified and analyzed simultaneously with SNPs to strengthen inferences about diversity, structure and genetic relationships ${ }^{61}$. However, they can also be identified by means of polyacrylamide gels or capillary sequencing equipment when fluorescently labeled ${ }^{5}$. As such, they provide accessible and profitable information for managing germplasm 
banks and promoting regional initiatives in developing countries that do not have the resources to access cutting-edge technology, yet view sericulture as an opportunity to generate employment and improve the conditions of the rural population ${ }^{1}$.

\section{Linkage maps}

Determination of the relative positions of microsatellite markers in the chromosomes of the $B$. mori genome began with the lowdensity linkage map developed by Prasad et al. ${ }^{16}$. The medium density one constructed by Miao et al. ${ }^{15}$ followed, with an average distance between markers of $6.3 \mathrm{cM}$ and 29 linkage groups. Zhan et al. ${ }^{20}$ subsequently increased the density of this map using new lines and mapping populations of $B$. mori, decreasing the average distance between markers to $4.8 \mathrm{cM}$ (Table 2).

The density achieved with the linkage map of SSR markers is below the results expected by the authors due to the high homology (low percentage of polymorphic loci) between the loci of the $B$. mori lines used to generate the mapping populations ${ }^{15,20}$. Nevertheless, the resolution is sufficient to carry out the preliminary gene screening (Table 3) and identification of QTLs.

Exclusive linkage maps for the $\mathrm{Z}$ chromosome were developed by Nagaraja et al. ${ }^{62}$ and Miao et al. ${ }^{63}$ with the purpose of contributing to identification of genes related to control of the duration of larval stages, diapause, moltinism, body size and color, etc., and to analyze the role played by characteristics linked to sex in evolutionary processes in Lepidoptera, and differentiation of geographic races ${ }^{64}$.

\section{Identification of genes and QTLs}

Identification of SSR markers linked to genes was carried out in order to understand the molecular basis of characteristics of agronomic and scientific interest. The SSR loci identified by Miao et al. ${ }^{15}$ and Zhan et al. ${ }^{20}$ enabled the identification of genes related to characteristics such as thermotolerance, resistance to the $\mathrm{Z}$ strain of the virus of densonosis in B. mori, tolerance to fluorinated compounds, and absence of wing scales; studies that were used to develop improved lines with marker-assisted selection ${ }^{9,65,66}$. Genes related to pigmentation patterns were also identified, in cocoons and larvae, and in development processes such as the formation of extremities, thoracic segments, cell adhesion and regulation of molting (Table 3).

Microsatellites have also allowed tracking of QTLs in B. mori related to weight of cocoon, cortex, pupa and filament ${ }^{10,20}$, which are mainly located on chromosome 1 where they are strongly linked to SSR loci (LOD>11.0), contribute significantly to phenotypic variation $(30 \%)$ and have a simultaneous effect on the above characteristics. The location of the QTLs in chromosome 1 was delimited to a region of $290 \mathrm{~kb}$, in which 12 candidate genes were identified that will allow study of the molecular mechanisms underlying these characters of agronomic interest in B. mori $^{10}$. Additionally, Gao et al. ${ }^{67}$ discovered that Bombyx mori Nuclear Polyhedrosis Virus (BmNPV) resistance is a polygenic characteristic.

Linkage maps with microsatellites have allowed us to advance in the knowledge of characteristics of economic interest in $B$. mori, as well as in the Lepidoptera genetic architecture. However, $\mathrm{Xu}$ et al. ${ }^{68}$ and Li et al. ${ }^{69}$ indicate that the most used models have not been adjusted according to the particular genetic characteristics of the silkworm, because they ignore the effects of gender and the presence of aquiasmatic meiosis, a process that implies the absence of chromosomal cross-linking in the germinal line of the females. As a result, these authors have proposed models that allow correcting the potential biases and lack of precision of the most used methods for mapping QTLs in B. mori. Xu et al. ${ }^{68}$ propose a statistical model to analyze QTLs in F2 populations, while Li et al. ${ }^{69}$ focus their method on the use of backcrossing and the rational selection of mapping populations to first identify the chromosomes with QTLs and subsequently their position.

\section{Conclusions and future work}

The microsatellites in B. mori have particular characteristics such as low frequency, low average number of locus repeats and grouping into "families". These are shared by Lepidoptera

Table 2. Data summary of linkage maps with microsatellites in B. mori.

\begin{tabular}{|c|c|c|c|c|c|}
\hline \multirow[t]{2}{*}{ Reference } & \multirow{2}{*}{$\begin{array}{l}\text { Number } \\
\text { of LGs }\end{array}$} & \multirow{2}{*}{$\begin{array}{l}\text { Individuals } \\
\text { analyzed }\end{array}$} & \multicolumn{3}{|c|}{ Number of markers } \\
\hline & & & Total & SSRs $\mathbf{s}^{\ddagger}$ & Others \\
\hline Prasad et al., $2005^{16}$ & $8[1]^{\S}$ & $60 \mathrm{BF} 1 \pi$ & 29 & 29 & 0 \\
\hline Miao et al., $2005^{15}$ & 29 [26] & $189 \mathrm{BF} 1$ & 547 & 518 & 29 \\
\hline Nagaraja et al., $2005^{62}$ & 1 & $55 \mathrm{BC} \mathrm{M}^{+\dagger}$ & 16 & 2 & 14 \\
\hline Miao et al., $2008^{63}$ & 1 & $188 \mathrm{BC} 1 \mathrm{M}$ & 8 & 6 & 2 \\
\hline Zhan et al., $2009^{20}$ & $30[28]$ & 188-190 BF1 & 692 & 692 & 0 \\
\hline
\end{tabular}

†LG: linkage groups

SSRs: microsatellite loci (Simple Sequence Repeats)

sNumbers in square brackets indicate linkage groups assigned to established linkage groups

"BF1: backcross

${ }^{+} \mathrm{BC} 1 \mathrm{M}$ : backcross with F1 male 
Table 3. Genes mapped using microsatellites in B. mori.

\begin{tabular}{|c|c|c|c|}
\hline Name & $\mathbf{L G}^{+}$ & Expression or function & Reference \\
\hline$n s d-Z$ & 15 & $\begin{array}{l}\text { Resistance to the virus of } \\
\text { densonucleosis }\end{array}$ & Li et al., $2006^{70}$ \\
\hline Sel & 24 & Yellow cuticle & Miao et al., $2007^{71}$ \\
\hline Xan & 24 & Yellow cuticle & Miao et al., $2007^{71}$ \\
\hline$B m a b d-A$ & 6 & Additional limb pair & Xiang et al., $2008^{72}$ \\
\hline C & 12 & Yellow pigmentation in cocoons & Zhao et al., $2008^{73}$ \\
\hline I & 9 & $\begin{array}{l}\text { Prevents absorption of } \\
\text { carotenoids }\end{array}$ & Li et al., $2008^{74}$ \\
\hline Dtf & 15 & $\begin{array}{l}\text { Resistance to fluorinated } \\
\text { compounds }\end{array}$ & Bai et al., $2008^{75}$ \\
\hline BM-iAANAT & 18 & $\begin{array}{l}\text { Larvae and pupae with dark } \\
\text { pigmentation }\end{array}$ & $\begin{array}{l}\text { Dai et al., 201076; } \\
\text { Zhan et al., 2010"77 }\end{array}$ \\
\hline$n / w$ & 13 & Scaleless wings & Wang et al., $2010^{78}$ \\
\hline KN & 8 & Thermotolerance & Zhao et al., $2010^{79}$ \\
\hline $\mathrm{Ng}$ & 12 & No glue eggs & Zhao et al., $2011^{80}$ \\
\hline BmAntp & 6 & Identify thoracic segments & Chen et al., $2013^{81}$ \\
\hline$E^{C s_{-}}$ & 6 & $\begin{array}{l}\text { Control abdominal segment } \\
\text { development }\end{array}$ & Chen et al., $2013^{82}$ \\
\hline BmEP80 & 10 & Egg dehydration & Chen et al., $2013^{83}$ \\
\hline$+P$ & 2 & Formation of larval marks & Wei et al., $2013^{84}$ \\
\hline$B m A D C$ & 11 & Black pupae & Dai et al., $2015^{11}$ \\
\hline BmLanB1-w & 13 & Cell adhesion in wing tissues & Tong et al., $2015^{85}$ \\
\hline$B m C P G 10$ & 5 & Regulation of molt & Wu et al., $2016^{12}$ \\
\hline Bmscarface & 23 & Regulation of body shape & Wang et al., $2018^{86}$ \\
\hline
\end{tabular}

tLG: linkage group where the gene is located

and seem to indicate that factors or mechanisms exist within the genome of this taxon that limit growth and stability of these repetitive DNA regions and their used as single copy loci molecular markers. Such as an abundance of loci SSR rich in A/T susceptible to double strand breaks and loss of repeats, as well as the possible existence of efficient DNA repair mechanisms that avoid the incorrect incorporation of bases (DNA mismatch repair) and the high association with transposons that would cause the formation of groups of loci with high similarity in their flanking regions.

The characteristics of the SSR loci in B. mori, and generally in all Lepidoptera, have made identification and isolation of these markers difficult. They have also been a limitation for applications in genetic mapping. The low frequency and high homology (low percentage of polymorphic loci) of the microsatellites between contrasting lines of B. mori, possibly due to the size homoplasy, has not allowed the development of high-density linkage maps. This, together with the absence of mapping models adjusted to this organism, has hindered identification of genes and QTLs, limiting contributions mainly to preliminary mapping, for example of regions related to pigmentation patterns and development processes, as well as to weight of cocoon, cortex, pupa and filament.

These regions of repetitive DNA, however, have shown a high discriminating power between $B$. mori lines due to the high level of polymorphism, the finding of a percentage of single alleles higher than $20 \%$, and the high levels of homozygosity in the materials analyzed, so that a reduced subset of 5-8 SSR loci have made it possible to generate DNA fingerprints, estimating the genetic diversity of domesticated and wild materials and determining the genetic relationships between closely related lines such as Dazao and P50. Although these markers additionally represent a potential tool for identifying $B$. mori cell lines, it is necessary to evaluate and select a subset of microsatellites with relatively low mutation rates that provide stability to the genetic profiles for 200 or more subcultures.

The data indicate that microsatellites will continue to be important for the study, management, conservation and use of silkworm germplasm. They have shown superior performance in these aspects compared to most molecular markers and are versatile - they can be analyzed, depending on resources available 
and expected reliability, with traditional polyacrylamide gels, with analysis of DNA fragments marked with fluorescence, or with the latest sequencing technologies. The latter, in addition to providing greater precision and automation in genotyping, would also facilitate identification of suitable SSR loci as molecular markers and allow simultaneous analysis with single nucleotide polymorphisms (SNPs), which would complement and strengthen the inferences and analyzes obtained when using them separately.

In this context, microsatellites would play an important role both in supporting the research carried out in B. mori germplasm banks in emerging countries wishing to promote sericulture in their territories, but that do not have the resources to access cutting-edge technologies and in advancing understanding of the complex genetic and molecular mechanisms underlying characteristics of productive and biological interest.
Data availability

No data are associated with this article.

\section{Grant information}

The author(s) declared that no grants were involved in supporting this work.

\section{Acknowledgments}

The authors are grateful to the University of Cauca and the following research groups for the scientific support: Integrated Systems of Agricultural, Forestry and Aquaculture Production (SISINPRO), Geology, Ecology and Conservation (GECO); we are also indebted to the "Technological Development for the Obtaining of Organic and Innovative Products of Natural Silk" project of the General System of Royalties and the Government of Cauca; and we are especially grateful to Colin McLachlan for suggestions related to the English text.
1. Sohn KW: Technical manual for tropical sericulture: practical technology to produce silkworm eggs and cocoons in the tropics. Kigali, Republica de Ruanda: Korea International Cooperation Agency (KOICA). 2014.

2. Petkov NI, Tzenov PI, Petkov ZM, et al.: Silkworm, Bombyx mori L. germplasm resources in Bulgaria. National Centre for Agrarian Sciences-Sofia, NorthWest Regional Agrotechpark - Vratza, Regional Centre for Scientific Applied Service - Vratza, Sericultural Experiment Station-Vratza. Sofia, Bulgaria: PublishScieSet - Eco. 2006; 264. Reference Source

3. Zhou Z, Yang H, Zhong B: From genome to proteome: great progress in the domesticated silkworm (Bombyx mori L.). Acta Biochim Biophys Sin (Shanghai). 2008; 40(7): 601-11.

PubMed Abstract | Publisher Full Text

4. Goldsmith MR: Recent progress in silkworm genetics and genomics. In: Goldsmith MR, Frantisek M, editors. Molecular biology and genetics of the lepidoptera. New York: CRC press, 2009; 25-48. Reference Source

5. Madesis P, Ganopoulos I, Tsaftaris A: Microsatellites: evolution and contribution. In: Kantartzi KS, editor. Microsatellites: methods and protocols. Totowa, NJ: Humana Press, Methods Mol Biol. 2013; 1006: 1-13. PubMed Abstract | Publisher Full Text

6. Nagaraju J, Reddy KD, Nagaraja GM, et al.: Comparison of multilocus RFLPs and PCR-based marker systems for genetic analysis of the silkworm, Bombyx mori. Heredity (Edinb). 2001; 86(Pt 5): 588-97. PubMed Abstract | Publisher Full Text

7. Furdui EM, Mărghitaş LA, Dezmirean DS, et al:: Genetic characterization of Bombyx mori (Lepidoptera: Bombycidae) breeding and hybrid lines with different geographic origins. J Insect Sci. 2014; 14(1): pii: 211. PubMed Abstract | Publisher Full Text | Free Full Text

8. Kim KY, Kang PD, Ryu KS, et al.: Microsatellite analysis of the silkworm strains (Bombyx mori) originated from China. Int $J$ Ind Entomol. 2012; 25(1): 81-92. Publisher Full Text

9. $\quad \mathrm{Li} \mathrm{MW}, \mathrm{Yu} \mathrm{HJ}, \mathrm{Yi} \mathrm{XL}$, et al:: Marker-assisted selection in breeding silkworm strains with high tolerance to fluoride, scaleless wings, and high silk production. Genet Mol Res. 2015; 14(3): 11162-70. PubMed Abstract | Publisher Full Text

10. Li B, Wang XY, Hou CX, et al.: Genetic analysis of quantitative trait loci for cocoon and silk production quantity in Bombyx mori (Lepidoptera: Bombycidae). Eur J Entomol. 2013; 110(2): 205-13. Publisher Full Text

11. Dai F, Qiao L, Cao C, et al.: Aspartate Decarboxylase is Required for a Normal Pupa Pigmentation Pattern in the Silkworm, Bombyx mori. Sci Rep. 2015; 5: 10885.

PubMed Abstract | Publisher Full Text | Free Full Text

12. Wu F, Wang $P$, Zhao $Q$, et al: Mutation of a Cuticle Protein Gene, BmCPG10,
Is Responsible for Silkworm Non-Moulting in the $2^{\text {nd }}$ Instar Mutant. PLoS One. 2016; 11(4): e0153549.

PubMed Abstract | Publisher Full Text | Free Full Text

13. Tóth G, Gáspári Z, Jurka J: Microsatellites in different eukaryotic genomes: survey and analysis. Genome Res. 2000; 10(7): 967-81.

PubMed Abstract | Publisher Full Text | Free Full Text

14. Reddy KD, Abraham EG, Nagaraju J: Microsatellites in the silkworm, Bombyx mori: abundance, polymorphism, and strain characterization. Genome. 1999; 42(6): 1057-65.

PubMed Abstract | Publisher Full Text

15. Miao XX, Xu SJ, Li MH, et al.: Simple sequence repeat-based consensus linkage map of Bombyx mori. Proc Natl Acad Sci U S A. 2005; 102(45): 16303-8. PubMed Abstract | Publisher Full Text | Free Full Text

16. Prasad MD, Muthulakshmi M, Madhu M, et al:: Survey and analysis of microsatellites in the silkworm, Bombyx mori: frequency, distribution, mutations, marker potential and their conservation in heterologous species. Genetics. 2005; 169(1): 197-214.

PubMed Abstract | Publisher Full Text | Free Full Text

17. Meglécz E, Anderson SJ, Bourguet $\mathrm{D}$, et al:: Microsatellite flanking region similarities among different loci within insect species. Insect Mol Biol. 2007; 16(2): 175-85

PubMed Abstract | Publisher Full Text

18. Van't Hof AE, Brakefield PM, et al: Evolutionary dynamics of multilocus microsatellite arrangements in the genome of the butterfly Bicyclus anynana, with implications for other Lepidoptera. Heredity (Edinb). 2007; 98(5): 320-8. PubMed Abstract | Publisher Full Text

19. Harr B, Schlötterer C: Long microsatellite alleles in Drosophila melanogaster have a downward mutation bias and short persistence times, which cause their genome-wide underrepresentation. Genetics. 2000; 155(3): 1213-1220. PubMed Abstract | Free Full Text

20. Zhan S, Huang J, Guo Q, et al: An integrated genetic linkage map for silkworm with three parental combinations and its application to the mapping of single genes and QTL. BMC Genomics. 2009; 10(1): 389

PubMed Abstract | Publisher Full Text | Free Full Text

21. Zhang DX: Lepidopteran microsatellite DNA: redundant but promising. Trends Ecol Evol. 2004; 19(10): 507-9.

PubMed Abstract | Publisher Full Text

22. International Silkworm Genome Consortium: The genome of a lepidopteran model insect, the silkworm Bombyx mori. Insect Biochem Mol Biol. 2008; 38(12): 1036-45.

PubMed Abstract | Publisher Full Text

23. Osanai-Futahashi M, Suetsugu $Y$, Mita K, et al:: Genome-wide screening and characterization of transposable elements and their distribution analysis in the silkworm, Bombyx mori. Insect Biochem Mol Biol. 2008; 38(12): 1046-57. PubMed Abstract | Publisher Full Text 
24. Ellegren $\mathrm{H}$ : Microsatellites: simple sequences with complex evolution. Nat Rev Genet. 2004; 5(6): 435-45.

PubMed Abstract | Publisher Full Text

25. Ji YJ, Zhang DX: Characteristics of microsatellite DNA in lepidopteran genomes and implications for their isolation. Acta Zool Sin. 2004; 50(4): 608-14. Reference Source

26. Meglécz E, Petenian F, Danchin E, et al:: High similarity between flanking regions of different microsatellites detected within each of two species of Lepidoptera: Parnassius apollo and Euphydryas aurinia. Mol Ecol. 2004; 13(6): 1693-700.

PubMed Abstract | Publisher Full Text

27. Shah $A B$, Schielzeth $H$, Albersmeier $A$, et al.: High-throughput sequencing and graph-based cluster analysis facilitate microsatellite development from a highly complex genome. Ecol Evol. 2016; 6(16): 5718-27. PubMed Abstract | Publisher Full Text | Free Full Text

28. Tay WT, Behere GT, Batterham P, et al:: Generation of microsatellite repeat families by RTE retrotransposons in lepidopteran genomes. BMC Evol Biol. 2010; 10(1): 144 .

PubMed Abstract | Publisher Full Text | Free Full Text

29. Kalia RK, Rai MK, Kalia S, et al:: Microsatellite markers: an overview of the recent progress in plants. Euphytica. 2011; 177(3): 309-34. Publisher Full Text

30. Pannunzio NR, Watanabe G, Lieber MR: Nonhomologous DNA end-joining for repair of DNA double-strand breaks. J Biol Chem. 2018; 293(27): 10512-23. PubMed Abstract | Publisher Full Text | Free Full Text

31. Wilder $\mathrm{J}$, Hollocher $\mathrm{H}$ : Mobile elements and the genesis of microsatellites in dipterans. Mol Biol Evol. 2001; 18(3): 384-92.

PubMed Abstract | Publisher Full Text

32. Liu R, Koyanagi KO, Chen S, et al.: Evolutionary force of AT-rich repeats to trap genomic and episomal DNAs into the rice genome: lessons from endogenous pararetrovirus. Plant J. 2012; 72(5): 817-28.

PubMed Abstract | Publisher Full Text

33. Kim KY, Kang PD, Lee KG, et al.: Microsatellite analysis of the silkworm strains (Bombyx mori): high variability and potential markers for strain identification. Genes Genomics. 2010; 32(6): 532-43.

Publisher Full Text

34. Kim KY, Kang PD, Kim MJ, et al:: Microsatellite analysis of silkworm strains (Bombyx mori) of japan origin preserved in Korea. Int J Ind Entomol. 2014; 28(2): 39-50.

Publisher Full Text

35. Hou CX, Li MW, Zhang YH, et al.: Analysis of SSR Fingerprints in Introduced Silkworm Germplasm Resources. Agric Sci China. 2007; 6(5): 620-7. Publisher Full Text

36. Chandrakanth N, Moorthy SM, Anusha P, et al.: Evaluation of genetic diversity in silkworm (Bombyx mori L.) strains using microsatellite markers. Int $J$ Biotechnol Allied Fields. 2014; 2(3): 73-93.

37. Li MW, Shen L, Xu AY, et al:: Genetic diversity among silkworm (Bombyx mori L., Lep., Bombycidae) germplasms revealed by microsatellites. Genome. 2005; 48(5): 802-10.

PubMed Abstract | Publisher Full Text

38. Khurad AM, Zhang MJ, Deshmukh CG, et al:: A new continuous cell line from larval ovaries of silkworm, Bombyx mori. In Vitro Cell Dev Biol Anim. 2009; 45(8): 414-9.

PubMed Abstract | Publisher Full Text

39. Khurad AM, Bahekar RS, Zhang MJ, et al:: Development and characterization of a new Bombyx mori cell line for protein expression. J Asia Pac Entomol. 2013; 16(1): 17-22.

Publisher Full Text

40. Xu M, Tan J, Wang X, et al:: Establishment and characterization of a new embryonic cell line from the silkworm, Bombyx mori. ISJ. 2015; 12(1): 13-8. Reference Source

41. McIntosh AH, Grasela JJ, Matteri RL: Identification of insect cell lines by DNA amplification fingerprinting (DAF). Insect Mol Biol. 1996; 5(3): 187-95. PubMed Abstract | Publisher Full Text

42. Schugl MD, Mackay TF, Aquadro CF: Low mutation rates of microsatellite loci in Drosophila melanogaster. Nat Genet. 1997; 15(1): 99-102.

PubMed Abstract | Publisher Full Text

43. Bindroo BB, Moorthy SM: Genetic divergence, implication of diversity, and conservation of silkworm, Bombyx mori. Int J Biodivers. 2014; 2014: 15 Publisher Full Text

44. Solignac $\mathrm{M}$, Vautrin $\mathrm{D}$, Baudry $\mathrm{E}$, et al:: A microsatellite-based linkage map of the honeybee, Apis mellifera L. Genetics. 2004; 167(1): 253-62. PubMed Abstract | Publisher Full Text | Free Full Text

45. Watanabe TK, Ono T, Okuno $\mathrm{S}$, et al: Characterization of newly developed SSLP markers for the rat. Mamm Genome. 2000; 11(4): 300-5. PubMed Abstract | Publisher Full Text

46. Xia QY, Guo YR, Zhang Z, et al:: Complete resequencing of $\mathbf{4 0}$ genomes reveals domestication events and genes in silkworm (Bombyx). Science. 2009; 326(5951): 433-6.

PubMed Abstract | Publisher Full Text | Free Full Text

47. Estoup A, Jarne P, Cornuet JM: Homoplasy and mutation model at microsatellite loci and their consequences for population genetics analysis. Mol Ecol. 2002;
11(9): 1591-604

PubMed Abstract | Publisher Full Text

48. De Barba M, Miquel C, Lobréaux S, et al:: High-throughput microsatellite genotyping in ecology: improved accuracy, efficiency, standardization and success with low-quantity and degraded DNA. Mol Ecol Resour. 2016; 17(3): 492-507.

PubMed Abstract | Publisher Full Text

49. Zhang L, Huang YP, Miao XX, et al:: Microsatellite markers application on domesticated silkworm and wild silkworm. Insect Sci. 2005; 12(6): 413-9. Publisher Full Text

50. Kômoto N, Tsuda M, Okada E, et al.: Development of methods for risk assessment of transgenic silkworms rearing on biodiversity. $J$ Insect Biotechnol Sericology. 2014; 83(2): 171-9. [in Japanese, English abstract]. Publisher Full Text

51. Qian HY, Xu AY, Zhang YH, et al.: Genetic diversity and molecular phylogenetics on silkworm, Bombyx mori. Journal-Shenyang Agric Univ. 2007; 38(3): 357-61. [in Chinese, English abstract]

52. Thiyagu T, Kamble CK: DNA profiling of bivoltine silkworm germplasm races through microsatellite markers. Int J Biotechnol. 2011; 4(2): 53-7.

53. Vijayan K, Nair CV, Urs SR: Assessment of genetic diversity in the tropical mulberry silkworm (Bombyx mori L.) with mtDNA-SSCP and SSR markers. Emir J Food Agr. 2010; 22(2): 71-83.

Publisher Full Text

54. Chu Q, Peng Y: Analysis of genetic relationship between color cocoon silkworm varieties by SSR markers. Hunan Agric Sci. 2013; 17: 13-6.

55. Raju PJ, Krishnamurthy NB: Breeding of two bivoltines, MG511 and MG512, of silkworm, Bombyx mori L., for higher viability and silk productivity. Sericologia (France). 1993; 33(4): 577-93.

56. Das SK, Sen SK, Saratchandra B: Improvement of commercial traits in mulberry silkworm Bombyx mori L by hybridization, Persp. Cytol Genet. 1998; 9: 101-8.

57. Das SK: Techniques of breeding for evolving improved breeds of bivoltine mulberry silkworm Bombyx mori. Cytol Genet. 2001; 10: 129-34.

58. Moorthy SM, Das SK, Kar NB, et al.: Breeding of Bivoltine breeds of Bombyx mori $L$ suitable for variable climatic conditions of the tropics. Int $J$ Ind Entomol. 2007; 14(2): 99-105

Reference Source

59. Lu C, Yu HS, Xiang ZH: Molecular systematic studies on Chinese mandarina silkworm (Bombyx mandarina M.) and domestic silkworm (Bombyx mori L.). Agric Sci China. 2002; 1(3): 349-58. [in Chinese, English abstract].

60. Dalirsefat SB, Mirhoseini SZ: Assessing genetic diversity in Iranian native silkworm (Bombyx mori L.) strains and Japanese commercial lines using AFLP markers. Iran J Biotechnol. 2007; 5(1): 25-33. Reference Source

61. Sorenson MD, DaCosta JM: Genotyping HapSTR loci: phase determination from direct sequencing of PCR products. Mol Ecol Resour. 2011; 11(6): 1068-75. PubMed Abstract | Publisher Full Text

62. Nagaraja GM, Mahesh G, Satish V, et al:: Genetic mapping of $\mathbf{Z}$ chromosome and identification of $\mathrm{W}$ chromosome-specific markers in the silkworm, Bombyx mori. Heredity (Edinb). 2005; 95(2): 148-57.

PubMed Abstract | Publisher Full Text

63. Miao XX, Li WH, Li MW, et al.: Inheritance and linkage analysis of co-dominan SSR markers on the Z chromosome of the silkworm (Bombyx mori L.). Gene Res (Camb). 2008; 90(2): 151-6.

PubMed Abstract | Publisher Full Text

64. Sperling F: Sex-linked genes and species differences in Lepidoptera. Can Entomol. 1994; 126(3): 807-18.

Publisher Full Text

65. Hou CX, Sun PJ, Guo XJ, et al:: Marker-assisted selection in breeding silkworm strains with high silk production and resistance to the densonucleosis virus. Genet Mol Res. 2013; 12(4): 4171-8. PubMed Abstract | Publisher Full Tex

66. Li MW, Hou CX, Zhao YP, et al:: Detection of homozygosity in near isogenic lines of non-susceptible to Zhenjiang strain of densonucleosis virus in silkworm. Afr J Biotechnol. 2007; 6(14): 1629-1633. Reference Source

67. Gao R, Li CL, Tong XL, et al.: Insight into genetic basis of Bombyx mori resistant strains with resistance to BmNPV by molecular linkage analysis. $S c i$ Agric Sin. 2017; 50(1): 195-204. Publisher Full Text

68. Xu HM, Wei CS, Tang YT, et al:: A new mapping method for quantitative trait loci of silkworm. BMC Genet. 2011; 12(1): 19. PubMed Abstract | Publisher Full Text | Free Full Text

69. Li C, Zuo W, Tong X, et al.: A composite method for mapping quantitative trait loci without interference of female achiasmatic and gender effects in silkworm, Bombyx mori. Anim Genet. 2015; 46(4): 426-32. PubMed Abstract | Publisher Full Text

70. Li M, Guo Q, Hou C, et al:: Linkage and mapping analyses of the densonucleosis non-susceptible gene nsd-Z in the silkworm Bombyx mori using SSR markers. Genome. 2006; 49(4): 397-402. PubMed Abstract | Publisher Full Text

71. Miao XX, Li MW, Dai FY, et al.: Linkage analysis of the visible mutations Sel and Xan of Bombyx mori (Lepidoptera: Bombycidae) using SSR markers. Eur J 
Entomol. 2007; 104(4): 647-52.

Publisher Full Text

72. Xiang $\mathrm{H}$, Li M, Yang F, et al.: Fine mapping of $\mathrm{E}^{\mathrm{kp}}$-1, a locus associated with silkworm (Bombyx mori) proleg development. Heredity (Edinb). 2008; 100(5): $533-40$.

PubMed Abstract | Publisher Full Text

73. Zhao YP, Li MW, Xu AY, et al:: SSR based linkage and mapping analysis of C, a yellow cocoon gene in the silkworm, Bombyx mori. Insect Sci. 2008; 15(5): 399-404

Publisher Full Tex

74. Li X, Li MW, Guo QH, et al.: Mapping of the yellow inhibitor gene I in silkworm Bombyx mori using SSR markers. Yi Chuan. 2008; 30(8): 1039-42. PubMed Abstract | Publisher Full Text

75. Bai $\mathrm{HC}, \mathrm{Xu}$ AY, Li MW, et al: SSR based linkage and mapping analysis of dominant endurance to fluoride gene (Def) in the silkworm, Bombyx mori. Acta Seric Sin. 2008; 34(2): 191-6. Reference Source

76. Dai FY, Qiao L, Tong XL, et al:: Mutations of an arylalkylamine-Nacetyltransferase, Bm-iAANAT, are responsible for silkworm melanism mutant. J Biol Chem. 2010; 285(25): 19553-60.

PubMed Abstract | Publisher Full Text | Free Full Text

77. Zhan S, Guo QH, Li MH, et al.: Disruption of an $\mathbf{N}$-acetyltransferase gene in the silkworm reveals a novel role in pigmentation. Development. 2010; 137(23): 4083-90.

PubMed Abstract | Publisher Full Text

78. Wang XY, Li MW, Zhao YP, et al:: Mapping of non-lepis wing gene nlw in silkworm (Bombyx mori) using SSR and STS markers. Yi Chuan. 2010; 32(1): 54-8. PubMed Abstract | Publisher Full Text

79. Zhao Y, Zhang J, Wu YC, et al:: SSR marker-based mapping and linkage analysis of Bombyx mori thermo tolerance gene. J Food Agric Environ. 2010 8(1): 338-42.

Reference Source

80. Zhao XM, Wei GQ, Liu CL, et al.: Linkage and mapping analyses of the no glue egg gene $\mathrm{Ng}$ in the silkworm (Bombyx mori L.) using simple sequence repeats (SSR) markers. African J Biotechnol. 2011; 10(47): 9549-56. Publisher Full Text

81. Chen P, Tong XL, Li DD, et al:: Antennapedia is involved in the development of thoracic legs and segmentation in the silkworm, Bombyx mori. Heredity (Edinb). 2013; 111(3): 182-8.

PubMed Abstract | Publisher Full Text | Free Full Text

82. Chen $\mathrm{P}$, Tong $\mathrm{XL}$, Li DD, et al:: Fine mapping of a supernumerary proleg mutant $\left(E^{\mathrm{Cs}}-\mathrm{I}\right)$ and comparative expression analysis of the abdominal-A gene in silkworm, Bombyx mori. Insect Mol Biol. 2013; 22(5): 497-504. Publisher Full Text

83. Chen $A$, Gao $P$, Zhao QL, et al:: Mutation of a vitelline membrane protein, BmEP80, is responsible for the silkworm "Ming" lethal egg mutant. Gene. 2013, 515(2): 313-9.

515(2): 313-9.
PubMed Abstract | Publisher Full Text

84. Wei GQ, Yu L, Liu CL, et al.: Linkage and mapping analyses of the normal marking gene $+\boldsymbol{P}$ in the silkworm (Bombyx mori) using SSR markers. Genet $\mathrm{Mol}$ Res. 2013; 12(3): 2351-9.

PubMed Abstract | Publisher Full Text

85. Tong $\mathrm{XL}, \mathrm{He} \mathrm{S}$, Chen J, et al:: A novel laminin $\beta$ gene BmLanB1-w regulates wing-specific cell adhesion in silkworm, Bombyx mori. Sci Rep. 2015; 5: 14 . PubMed Abstract | Publisher Full Text | Free Full Text

86. Wang RX, Tong XL, Gai TT, et al:: A serine protease homologue Bombyx mori scarface induces a short and fat body shape in silkworm. Insect Mol Biol. 2018; 27(3): 319-32.

PubMed Abstract | Publisher Full Text 


\section{Open Peer Review}

\section{Current Peer Review Status:}

\section{Version 1}

Reviewer Report 24 February 2020

https://doi.org/10.5256/f1000research.22017.r59560

(C) 2020 Carneiro Vieira M. This is an open access peer review report distributed under the terms of the Creative Commons Attribution License, which permits unrestricted use, distribution, and reproduction in any medium, provided the original work is properly cited.

\section{Maria-Lucia Carneiro Vieira}

Departamento de Genética, Escola Superior de Agricultura "Luiz de Queiroz", Universidade de São Paulo, São Paulo, Brazil

I do believe that the review should be useful for readers, it considers the state of the art on the role of microsatellitesfor the genetic analysis of Bombyx mori silkworm. The most recent citation dates from 2018; therefore, I suggest authors to search for more recent articles on other Lepidoptera of agronomic importance. The population of these pests tend to have the same genetic structure as the ones of Bombyx mori silkworm? Please make the comparison.

\section{References}

1. Vieira ML, Santini L, Diniz AL, Munhoz Cde F: Microsatellite markers: what they mean and why they are so useful.Genet Mol Biol. 39 (3): 312-28 PubMed Abstract | Publisher Full Text

Is the topic of the review discussed comprehensively in the context of the current literature?

Yes

Are all factual statements correct and adequately supported by citations? Yes

Is the review written in accessible language?

Yes

Are the conclusions drawn appropriate in the context of the current research literature? Yes

Competing Interests: No competing interests were disclosed.

Reviewer Expertise: Plant genetics and genomics 


\section{I confirm that I have read this submission and believe that I have an appropriate level of expertise to confirm that it is of an acceptable scientific standard.}

Reviewer Report 28 October 2019

https://doi.org/10.5256/f1000research.22017.r54605

(C) 2019 Chandrakanth N. This is an open access peer review report distributed under the terms of the Creative Commons Attribution License, which permits unrestricted use, distribution, and reproduction in any medium, provided the original work is properly cited.

\section{Nalavadi Chandrakanth}

Silkworm Breeding and Biotechnology, Central Sericultural Research and Training Institute, Berhampore, India

The authors have scripted the manuscript properly and covered the appropriate and relevant literature necessary for understanding the characteristics of microsatellite and the evolutionary events associated with it in Bombyx mori genome. Further this review has focused on the literature pertaining to the applications of the microsatellite as markers, in genetic analysis studies and in construction of the linkage maps in B. mori. Interestingly, the authors have also discussed about the lacuna of using microsatellite in marker-trait association studies and construction of high density linkage maps in B. mori. The authors have brought out an important point that linkage map construction in silkworm cannot be adjusted to the other models due to their gender based effects and absence of chromosomal cross-linking in the germinal line of the female silkworms. In this line, recently proposed statistical models to analyze QTLs were also reported and explained in this manuscript.

\section{Comments}

In the last paragraph of Introduction, it was mentioned that this review will focus on the roles or strategies involving microsatellite markers for conservation of silkworm germplasm. But, in future scope, this part has to be included with effective strategies to conserve the silkworm germplasm using microsatellite markers. In addition, the authors can also report in the future scope about how these microsatellite markers has been employed in breeding programs to improve the genetic materials of different silkworms.

In some parts of the manuscript, the sentences are very lengthy which can be simplified.

Is the topic of the review discussed comprehensively in the context of the current literature?

Yes

Are all factual statements correct and adequately supported by citations?

Yes

Is the review written in accessible language? 
Yes

Are the conclusions drawn appropriate in the context of the current research literature? Yes

Competing Interests: No competing interests were disclosed.

Reviewer Expertise: Silkworm Breeding and Biotechnology

I confirm that I have read this submission and believe that I have an appropriate level of expertise to confirm that it is of an acceptable scientific standard.

The benefits of publishing with F1000Research:

- Your article is published within days, with no editorial bias

- You can publish traditional articles, null/negative results, case reports, data notes and more

- The peer review process is transparent and collaborative

- Your article is indexed in PubMed after passing peer review

- Dedicated customer support at every stage

For pre-submission enquiries, contact research@f1000.com 